\title{
Efektivitas lumatan daun sirih hijau dibandingkan dengan povidine iodine sebagai alternatif obat luka
}

\author{
${ }^{1}$ Edriani Fitri \\ ${ }^{1}$ Ratih Annisa \\ ${ }^{1}$ Dian Nitari \\ ${ }^{1}$ Dewi K. Mubela \\ ${ }^{1}$ Kasih Santika \\ ${ }^{2}$ Hendra Sutysna
}

\author{
${ }^{1}$ Program Studi Pendidikan Dokter \\ ${ }^{2}$ Departemen Anatomi Fakultas Kedokteran \\ Universitas Muhammadiyah Sumatera Utara \\ Email: edriani_fitri@yahoo.co.id
}

\begin{abstract}
Betel leaf can be used as an antiseptic. Its chemical contents are saponins, flavonoids, polyphenols, and essential/aetheric oil. Saponins may act as antimicrobials by damaging cytoplasmic membranes and lead to cell death. The flavonoids are thought to act by of denaturing bacterial cell proteins and damaging the cell membranes irreversibly. Medically, $10 \%$ povidone iodine could speed up wound healing. However, traditionally, a number of plants have been used to prevent inflammation and to improve wound healing. This study was aimed to determine the effectiveness of betel leaf on wound healing in rabbits. This was an experimental study with the post control only controlled group design. Samples were obtained randomly. The Mann-Whitney test showed a $P$-value of 0.000 on wound healing and a $P$-value of 1.000 on infection. Conclusion: There was a significant difference in improvement of wound healing between betel leaf and $10 \%$ povidine iodine application but there was no significant difference between them in prevention of infection.
\end{abstract}

Keywords: betel leaf, incision wound, povidone iodine

\begin{abstract}
Abstrak: Daun sirih bisa digunakan sebagai antiseptik. Kandungan kimia dari tanaman sirih ialah saponin, flavonoid, polifenol, dan minyak atsiri. Senyawa saponin dapat bekerja sebagai antimikroba dengan merusak membran sitoplasma dan membunuh sel. Senyawa flavonoid diduga memiliki mekanisme kerja mendenaturasi protein sel bakteri dan merusak membran sel tanpa dapat diperbaiki lagi. Secara medis, untuk mempercepat penyembuhan luka bisa diolesi povidone iodine $10 \%$, tetapi secara tradisional sejumlah tanaman telah digunakan untuk mencegah peradangan dan penyembuhan luka. Penelitian ini bertujuan untuk mengetahui efektivitas daun sirih terhadap penyembuhan luka pada kelinci. Jenis penelitian ialah eksperimental dengan post test only controlled group design. Sampel penelitian diambil secara acak (random). Hasil uji Mann-Whitney menunjukkan nilai $P=0,000$ pada parameter penyembuhan luka dan memiliki perbedaan bermakna sedangkan pada parameter infeksi nilai $P$ 1,000 $(P>0,05)$ tidak memiliki perbedaan bermakna. Simpulan: Terdapat perbedaan bermakna dalam penyembuhan luka antara aplikasi daun sirih dan povidine iodine $10 \%$ tetapi tidak dalam terjadinya infeksi.
\end{abstract}

Kata kunci: daun sirih,luka insisi , povidone iodine

Luka digambarkan sebagai gangguan dalam kontinuitas sel-sel yang kemudian diikuti dengan penyembuhan luka. ${ }^{1}$ Luka harus dirawat, tidak bisa dibiarkan sembuh 
sendiri, karena dapat menyebabkan komplikasi penyembuhan luka yaitu bisa terjadi infeksi dan perdarahan. ${ }^{2}$

Secara medis, untuk mempercepat penyembuhan luka bisa diolesi povidone iodine $10 \%$, tetapi secara tradisional sejumlah tanaman telah digunakan untuk mencegah peradangan dan penyembuhan luka. Daun sirih bisa digunakan sebagai antiseptik. Kandungan kimia dari tanaman sirih ialah saponin, flavonoid, polifenol, dan minyak atsiri. Senyawa saponin dapat bekerja sebagai antimikroba. Senyawa ini akan merusak membran sitoplasma dan membunuh sel. Senyawa flavonoid diduga memiliki mekanisme kerja mendenaturasi protein sel bakteri dan merusak membran sel tanpa dapat diperbaiki lagi. ${ }^{3}$

Daun sirih mempunyai aroma yang khas karena mengandung minyak atsiri 14,2\%, air, protein, lemak, karbohidrat, kalsium, fosfor, vitamin A, B, C, yodium, gula dan pati. Dari berbagai kandungan tersebut, dalam minyak atsiri terdapat fenol alam yang mempunyai daya antiseptik 5 kali lebih kuat dibandingkan dengan fenol biasa (bakterisid dan fungisid) tetapi tidak sporasid. Minyak atsiri dari daun sirih mengandung $30 \%$ fenol dan beberapa derivatnya. Minyak atsiri terdiri dari hidroksi kavikol, kavibetol, estragol, eugenol, metileugenol, karbakrol, terpen, seskuiterpen, fenilpropan, dan tannin, Kavikol merupakan komponen paling banyak dalam minyak atsiri yang memberi bau khas pada sirih. Kavikol bersifat mudah teroksidasi dan dapat menyebabkan perubahan warna. ${ }^{4}$

Daun sirih juga memiliki efek antibakteri terhadap Streptococcus mutans, Streptococcus sanguins, Streptococcus viridans, Actinomyces viscosus, dan Staphylococcus aureus. ${ }^{5}$

Penelitian ini bertujuan untuk membandingkan efektifitas lumatan daun sirih hijau (Piper betle L.) dengan povidone iodine sebagai alternatif obat luka pada luka insisi kelinci.

\section{METODE PENELITIAN}

Jenis penelitian ini ialah eksperimental dengan post test only controlled group design. Hewan uji yang digunakan ialah kelinci New Zealand, berusia 8-12 minggu dan berat badan 2500-3000 gr. Jumlah sampel sebanyak 22 ekor kelinci yang dibagi menjadi dua kelompok yaitu 8 ekor kelinci kelompok perlakuan dan 8 ekor kelinci kelompok kontrol, serta cadangan untuk masing-masing kelompok 3 ekor. Sebelum diberikan perlakuan, kelinci $\mathrm{New}$ Zealand diadaptasikan selama 7 hari.

\section{HASIL PENELITIAN DAN BAHASAN}

Hasil penelitian berupa data jumlah skor pada penilaian makroskopik penyembuhan luka yang dihitung pada hari ke-7 dengan menggunakan kriteria Nagaoka.

Pada hari ke-7 didapatkan penyembuhan luka pada kelompok kontrol povidone iodine dan kelompok perlakuan dengan daun sirih. Tabel 1 dan 2 memperlihatkan hasil penilaian skor makroskopik pada masing-masing kelompok.

Tabel 1. Skor penelitian makroskopik penyembuhan luka kelompok kontrol

\begin{tabular}{cccccc}
\hline No & $\begin{array}{c}\text { Panjang luka yang } \\
\text { belum tertutup }\end{array}$ & Skor & Infeksi lokal & Skor & Jumlah skor \\
\hline 1 & $2 \mathrm{~cm}$ & 1 & - & 1 & 2 \\
2 & $1,5 \mathrm{~cm}$ & 1 & - & 1 & 2 \\
3 & $2 \mathrm{~cm}$ & 1 & - & 1 & 2 \\
4 & $2 \mathrm{~cm}$ & 1 & - & 1 & 2 \\
5 & $0 \mathrm{~cm}$ & 3 & - & 1 & 4 \\
6 & $1,5 \mathrm{~cm}$ & 1 & - & 1 & 2 \\
7 & $2 \mathrm{~cm}$ & 1 & - & 1 & 2 \\
8 & $1 \mathrm{~cm}$ & 2 & - & 1 & 3 \\
9 & $0 \mathrm{~cm}$ & 1 & - & 1 & 2 \\
10 & $0 \mathrm{~cm}$ & 1 & - & 1 & 2 \\
\hline
\end{tabular}


Tabel 2. Skor penelitian makroskopik penyembuhan luka kelompok perlakuan

\begin{tabular}{cccccc}
\hline No & $\begin{array}{c}\text { Panjang luka yang } \\
\text { belum tertutup }\end{array}$ & Skor & Infeksi lokal & Skor & Jumlah skor \\
\hline 1 & $0 \mathrm{~cm}$ & 1 & - & 1 & 2 \\
2 & $2 \mathrm{~cm}$ & 3 & - & 1 & 4 \\
3 & $2 \mathrm{~cm}$ & 3 & - & 1 & 4 \\
4 & $2 \mathrm{~cm}$ & 3 & - & 1 & 4 \\
5 & $2 \mathrm{~cm}$ & 3 & - & 1 & 4 \\
6 & $2 \mathrm{~cm}$ & 3 & - & 1 & 4 \\
7 & $2 \mathrm{~cm}$ & 3 & - & 1 & 4 \\
8 & $2 \mathrm{~cm}$ & 3 & - & 1 & 4 \\
9 & $1,5 \mathrm{~cm}$ & 3 & - & 1 & 4 \\
$\mathbf{1 0}$ & $0 \mathrm{~cm}$ & 1 & - & 1 & 2 \\
\hline
\end{tabular}

Hasil pengamatan secara makroskopik yang dilakukan pada hari ke-7 (Tabel 3) menunjukkan bahwa rerata jumlah skor pada kelompok kontrol (K) ialah 1,30 (SD $\pm 0,674)$ sedangkan kelompok perlakuan (P) yang diberi lumatan daun sirih sebanyak 1 kali sehari memiliki rerata skor yang lebih tinggi dari kelompok kontrol $(\mathrm{K})$ yaitu 2,60 $(\mathrm{SD} \pm 0,843)$.

Tabel 3. Rerata jumlah skor makroskopik penyembuhan luka masing-masing kelompok percobaan pada hari ke-7

\begin{tabular}{lcc}
\hline Kelompok & Mean & $\begin{array}{c}\text { Standar } \\
\text { Deviasi }\end{array}$ \\
\hline Kontrol (K) & 1,30 & 0,674 \\
Perlakuan & 2,60 & 0,843 \\
\hline
\end{tabular}

Normalitas data tersebut kemudian diuji dengan menggunakan uji Shapiro Wilk yang menunjukkan nilai signifikansi pada data jumlah skor makroskopik kelompok K ialah 0,000 dan kelompok $\mathrm{P}$ 0,000 . Hasil ini menunjukkan bahwa data pada kelompok $\mathrm{K}$ dan $\mathrm{P}$ berdistribusi tidak normal $(P<0,05)$. Kemudian dilakukan uji homogenitas menggunakan Levene statistic dan didapatkan nilai $P=0,000$ untuk data jumlah skor makroskopik. Dapat disimpulkan bahwa terdapat perbedaan varians antara kelompok yang dibandingkan (varians dan tidak homogen) yang ditandai dengan $P<0,05$. Oleh karena data berdistribusi tidak normal dan varians data tidak homogeni, maka analisis data ditransformasi menggunakan uji KruskallWallis yang mendapatkan semua kelompok memiliki perbedaan bermakna dan dilanjutkan dengan uji Mann-Whitney.

Pada penyembuhan luka terdapat perbedaan dengan nilai rerata ranking 5,50 pada kelompok $\mathrm{K}$, dan 15,50 pada kelompok $\mathrm{P}$ (Tabel 4), namun parameter infeksi tidak menunjukkan perbedaan antara kelompok K dan kelompok P (Tabel 4). Dengan uji Mann-Whitney, diperoleh nilai $P=0,000$ pada parameter penyembuhan luka yang memiliki perbedaan bermakna sedangkan pada parameter infeksi nilai $P 1,000(P>0,05)$ yang berarti tidak memiliki perbedaan bermakna (Tabel 5).

Tabel 4. Nilai rerata peringkat (mean rank) pada uji Mann-Whitney

\begin{tabular}{llccc}
\hline & Kelompok & N & Mean Rank & Sum of ranks \\
\hline \multirow{2}{*}{ Panjang luka } & Kontrol & 10 & 5,50 & 55,00 \\
& Perlakuan & 10 & 15,50 & 155,00 \\
& Total & 20 & & \\
& Kontrol & 10 & 10,50 & 105,00 \\
\multirow{2}{*}{ Infeksi } & Perlakuan & 10 & 10,50 & 105,00 \\
& Total & 20 & & \\
\hline
\end{tabular}


Fitri, Annisa, Nitari, et al: Efektivitas lumatan daun sirih hijau dibandingkan ...

Tabel 5. Hasil uji Mann-Whitney pada penilaian makroskopik

\begin{tabular}{lccc}
\hline \multicolumn{1}{c}{ Parameter } & $\begin{array}{c}\text { Pasangan } \\
\text { Kelompok }\end{array}$ & $\begin{array}{c}\text { Signifikan } \\
(\boldsymbol{P})\end{array}$ & Simpulan \\
\hline Penyembuhan luka & K vs P & 0,000 & Berbeda bermakna \\
Infeksi & K vs P & 1,000 & Tidak bermakna \\
\hline
\end{tabular}

Pada hasil pengamatan secara makroskopik yang dilakukan pada hari ke7, hampir semua sampel pada kelompok kontrol dan kelompok perlakuan mengalami penyembuhan luka dengan indikator penyembuhan luka seperti pada Tabel 1 dan 2 namun rerata jumlah skor kelompok $\mathrm{P}$ lebih besar dibanding dengan kelompok $\mathrm{K}$; hal ini menandakan bahwa penyembuhan luka lebih lambat.

Berdasarkan parameter infeksi yang dilihat pada Tabel 4 dan 5, kelompok kontrol dan kelompok perlakuan tidak memiliki perbedaan sehingga hal ini menandakan bahwa kelompok kontrol maupun perlakuan dapat menghambat terjadinya infeksi.

Pemberian lumatan daun sirih memberikan efek penyembuhan luka yang ditandai dengan penutupan luka walaupun lebih lambat daripada penyembuhan luka yang diolesi povidone iodine. Hal ini terjadi dimungkinkan karena lumatan daun sirih memiliki kandungan yang berkhasiat dalam menyembuhkan luka, seperti yang dilaporkan oleh Imas et al. ${ }^{6}$ Selain itu lumatan daun sirih juga dapat mencegah infeksi pada luka insisi seperti povidone iodine karena pada tanaman sirih terdapat kandungan kimia saponin, flavonoid, polifenol, dan minyak atsiri. Senyawa saponin dapat bekerja sebagai antimikroba dengan merusak membran sitoplasma dan membunuh sel. Senyawa flavonoid diduga memiliki mekanisme kerja mendenaturasi protein sel bakteri dan merusak membran sel tanpa dapat diperbaiki lagi. ${ }^{3}$

Dari analisis data, pemberian lumatan daun sirih sebanyak 1 kali sehari pada kelompok $\mathrm{P}$ berpengaruh pada penyembuhan luka walaupun lebih lambat dari pada penyembuhan oleh povidone iodine. Didapatkan perbedaan bermakna antara kelompok kontrol dan kelompok perlakuan
$(P=0,000)$. Selain itu, pemberian lumatan daun sirih pada kelompok $\mathrm{P}$ dan povidone iodine pada kelompok $\mathrm{K}$ dapat mencegah infeksi. Hal tersebut dilihat dari nilai $P=1,000 \quad(P>0,05)$ yang berarti tidak memiliki perbedaan bermakna dalam pencegahan infeksi antara pemberian lumatan daun sirih dan povidone iodine.

\section{SIMPULAN}

Pemberian lumatan daun sirih hijau (Piper betle L.) terhadap luka insisi memberikan proses penyembuhan luka walaupun lebih lambat dari pada povidone iodine namun lumatan daun sirih dapat mencegah infeksi ditinjau dari tidak terdapatnya tanda-tanda infeksi lokal.

\section{SARAN}

1. Pada penelitian selanjutnya sebaiknya terdapat indikator penyembuhan luka lainnya selain pengamatan makroskopik, misalnya dengan pengamatan secara mikroskopik

2. Pada penelitian lebih lanjut disarankan untuk membandingkan efektifitas lumatan daun sirih dalam penyembuhan luka dengan berbagai produk kimia penyembuhan luka yang telah banyak beredar di pasaran selain povidone iodine.

Ucapan terima kasih ditujukan kepada pihak Dikti yang telah memberikan pendanaan untuk penelitian ini serta pihak kampus yang mendukung penelitian ini. Selain itu peneliti juga mengucapkan terima kasih kepada semua pihak yang telah memberikan ide, saran, dan kritik yang membantu penyelesaian penelitian ini.

\section{DAFTAR PUSTAKA}

1. Bare BG, Smeltzer SC. Buku Ajar Keperawatan Medikal Bedah. Jakarta: 
EGC, 2001.

2. Sjamsuhidajat R, de Jong W. Buku Ajar Ilmu Bedah (3rd ed). Jakarta: EGC, 2010.

3. Aiello SE. The Merck Veterinary Manual. USA: Merck Sharp \& Dohme Corp, 2012.

4. Moeljanto RD, Mulyono. Khasiat dan Manfaat Daun Sirih, Obat Mujarab dari Masa ke Masa. Jakarta: Penebar Swadaya, 2003.
5. Irmasari A. Perbandingan daya antibakteri antara gerusan daun sirih hitam, sirih Jawa dengan oksitetrasiklin terhadap Staphylococcus aureus secara in vitro. Surabaya: Fakultas Kedokteran Hewan Universitas Airlangga; 2002.

6. Imas. Pengaruh tumbukan daun sirih terhadap proses percepatan penyembuhan luka insisi. Surabaya; Universitas Muhammadiyah Surabaya; 2015. 